\title{
Reading Difference in Identity: Lacanian Reasoning in Paul Auster's Invisible
}

\author{
Javad Momeni (Corresponding author) \\ English Language and Literature Department, University of Tehran, Tehran, Iran \\ E-mail: j.momeni364@yahoo.com \\ Bahare Jalali Farahani \\ English Language and Literature Department, Kharazmi University, Tehran, Iran \\ E-mail: jalali.bf@gmail.com
}

Doi:10.7575/aiac.alls.v.8n.3p.82

URL: http://dx.doi.org/10.7575/aiac.alls.v.8n.3p.82
Received: 07/04/2017

Accepted: 11/06/2017

\begin{abstract}
The prevailing motifs of Auster's literary oeuvre such as chance, contingent events, writing and the binary opposition of reader and author are also noticeable in Paul Auster's Invisible; however, in this article, we examine the novel in terms of the characters' psychological attempts to form their different identifications within Lacanian theoretical framework. Born acts as both reified big Other and object petit a for Walker, while Walker, in his different encounters with Born, experiences disparate Zizekian parallax views. Holding such views, Walker stands in the middle of the various courses of subjectivities, thereby undergoing a complicated interwoven subjectivity. Furthermore, Born's encounters with the Real, epitomized in Born, place him in the two concurrent positions of subjectivities both in the Imaginary and the Symbolic order. As a result, his constant Symbolic identifications with signifying traits of Born's bring him nothing but an aporia of logical perplexities. Last but not the least, we emphasize that the fluctuation between lost object and the loss itself, as an object, plums the depth of the anxieties embedded in such interwoven subjectivity.
\end{abstract}

Keywords: identification, parallax, subjectivity, imaginary, symbolic,

\section{Introduction: The Metaphysics of Chance}

Auster's literary world is full of the contingent events; in his writings, Auster puts emphasis on the incessant presence of chance and random occurrences. That Auster' highlights chance, moreover, alludes to his status as "a selfconsciously postmodern author (Martin ix)." This metaphysics of chance is usually portrayed in urban environments. New York City functions as a background to many of Auster's novels, and Auster invokes the postmodern idea of urban displacement so as to incorporate into his fictional world the mental confusions the so-called postmodern subject undergo (Woods 140-157). The conception of the author is another issue that Auster submits into scrutiny. He confirms the fact that the author must analyze the ambiance in which he lives, and criticize the norms commonly accepted by the populace or even elite communities. He advances this attitude to the authorship insofar as he intentionally creates literary scenes which stand in a sharp contrast to old or modern literary, sociological, political and psychological theories, as if he decide to take revenge of such theories by making scenes repudiating their validity (Zilcosky 64-76).

In Auster's view, and particularly in his analysis of writing itself, the author is an impossible individual with no life of his or hers. Auster's postmodern ruminations on authorship consider the author as a linguistic entity detached from the writing process, while the reader is regarded as the one who has to determine the fate of Auster's diverse, and sometimes identical, protagonists. Such deconstruction is not restricted to the binary opposition of author and reader. Auster progresses this literary strategy to the degree that he blurs the distinguishing line between different genres (Russell 98-107).

Auster's most widely-praised book is The New York Trilogy (1987), which includes three short novels, City of Glass (1985), Ghosts (1986), and The Locked Room (1986). This book has received much critical acclaim, whether for each component part or for the whole work. City of Glass which was first published in 1985 is full of fascinating literary techniques which engage readers in a complicated web of events. In Ghosts, a combination of the plague-ridden city's discipline diagrams and Panopticism make the whole scene of Auster's novel. By focusing on the role of writing in power mechanisms depicted in the novel, Auster illustrates the Foucauldian power-knowledge relations which involve the characters in the process of subjectification and which construct the subject position of the author who acts as the (in)visible eye of authority (Momeni and Mohsenzadeh 82). In the ongoing years, Auster has produced a wide range of novels, literary non-fictions and autobiographical pieces, including Invention of Solitude (1982), Hand to mouth (1997) and Winter Journal (2012). The obvious postmodern literary devices employed by Auster in his first major work has influenced and determined all of Auster's subsequent writings. Indeed, Auster's later novels, Moon Palace (1989), Leviathan (1992), The Brooklyn Follies (2005), Travels in the Scriptorium (2006),Man in the Dark (2008) and Sunset 
Park (2010) reveal Auster's social and political analysis of the policies imposed by the American governments but Auster's prevalent themes are easily noticeable there, too. In Moon Palace,

What most troubles ... Auster ... is the loss of a unique chance, the loss of a contingent but symbolically rich ground for innovative cultural contact, a chance he sees as having been destroyed under the wheels of an obsessively lineal narrative of progress and destiny (Weisenburger 179).

Leviathan, also, attempts to unravel the intermingled relations between author' life and his creative fictional world in the ground of dense metaphors and metonymies he uses to conceal his personal and psychic life (Fleck 208-210). However, Oracle Nights(2003), written in the aftermath of the September 11, 2001 devastation of New York City's World Trade Center, is a remarkable contrast to some of Auster's early writings. Here, Auster writes from a viewpoint that pays special attention to the fleeting nature of human existence which is informed by unjustified and unexpected presence of chance (Brendan Martin 33). Among Auster's literary oeuvre, his Invisible(2009), enjoys a special status. It has attracted a range of opposing critical attentions, both positive admiration and negative reprimand. Although the aforementioned motifs are also prevalent in Invisible, in this article, we intend to illuminate how Auster's characters, particularly Born and Walker, lead their subjective life and how their fragmented identity is actually made out of the different trends of subjectivities they adopt, whether consciously or unconsciously.

\section{Lacanian Orders}

Prior to any discussion of Lacanian concepts, we must shed light on his conceptualization of three orders, the Real, the Symbolic and the Imaginary. For Lacan, the Real order depicts the pre-symbolic state which we have abandoned forever by entering the world of language, a state in which we undergo our compulsory needs with a sense of fullness and completeness. Lacan delineates the Real in relation to the two other dimensions - the symbolic and the imaginary and considers them to "constitute the triadic (Borromean) structure of all being" (Zizek and Daly 6). For Lacan, what we call reality (which is different from the real) is enunciated "through signification (the symbolic) and the characteristic patterning of images (the imaginary)" (ibid). In its mechanism, the imaginary bears a resemblance to the mirror stage where the infant suddenly spots out of a whole image of self in an actual mirror or in the eyes of the others which stands in contrast to his primal sense of fragmented body. While the imaginary is redolent with the images with which we identify, the symbolic is the world of language. Only once we are introduced into language and the laws of society, we are given the ability to behave toward the others. For Lacan, complying with language's rules is concomitant with the Oedipus complex. In fact, the symbolic is realized only by our surrendering to the Name-of-the-Father, the rules and boundaries which regulate both our desires and our fantasies and which allow us to live as a human speaking subject in the community of signifying others (Stavrakakis, Lacan and the Political 20-31). The Real, however,

... does not belong to the (symbolic-imaginary) order of signification but is precisely that which negates the latter; that which cannot be incorporated within such an order. The Real persists as an eternal dimension of lack and every symbolic-imaginary construction exists as a certain historical answer to that basic lack (Zizek and Daly 7).

Indeed, this basic lack shows itself in the gaps and holes we experience thorough the symbolic order. By these gaps, the Real always forces "limits of negation" on the signifying and discursive order, but it is through these very limitations that the Real helps to form such an order. As Daly states, "The Real in this sense is strictly inherent to signification: it is both the unsurpassable horizon of negativity for any system of signification and its very condition of possibility (ibid)."

\section{Two Men in One order}

Told in retrospect, Invisible relates the story of a young man's life, Adam Walker, a Columbia university student whose life undergoes a lot of changes when he meets Rudolf Born, a French political science professor. The names are of significance in this novel, Adam Walker just like biblical Adam becomes derailed from the ordinary path of life and is transformed into a new person the moment he meets Rudolf Born, and actually Born seems just like Satan that comes forward with an enticing offer of a job. In the beginning of the novel when Adam hears the Born's name, he remembers his namesake in Dante's hell:

I had already met his namesake in Dante's hell, a dead man shuffling through the final verses of the twenty-eighth canto of the Inferno. Bertran de Born, the twelfth-century Provençal poet, carrying his severed head by the hair as it sways back and forth like a lantern-surely one of the most grotesque images in that book-length catalogue of hallucinations and torments. Dante was a staunch defender of de Born's writing, but he condemned him to eternal damnation for having counseled Prince Henry to rebel against his father, King Henry II, and because de Born caused division between father and son and turned them into enemies, Dante's ingenious punishment was to divide de Born from himself (Auster 9).

Given the text above, like Bertran de Born, the main Born of this novel is the cause of division of not two different people but the cause of the division between two identities within Adam Walker, who as a young person has hopes within the heart of the symbolic order. Unlike Rudolf Born who has experienced war and gruesome side of life, Walker associates people with their root, their core, just as we see in the previous paragraph. Walker's hopes lies in the symbolic order which, according to Lacan, is "inconsistent, self-contradictory, thwarted, traversed by antagonisms, without any guarantee ('there is no Other of Other'), with no ultimate norm or rule totalizing it-in short, the big Other is not some kind of substantial Master who secretly pulls the strings but a stumbling malfunctioning machinery (Zizek, The Most Sublime Hysterics 14)." In regard to Born, he is a reified object for Walker; he doesn't act like a 
transcendental and ultimate norm but triggers off an antagonistic division within walker's psychic life.

In a conversation between Walker and Born, the idealistic attitude held by Walker becomes clear. On the other hand, what we find out about Born's comments as to war points out the Freudian concept of death drive:

Never underestimate the importance of war. War is the purest, most vivid expression of the human soul. You're beginning to sound like our headless poet (Auster 11).

What we get from these two lines is how these two contrary attitudes clash; Walker who seeks to fill the gap he feels in his symbolic order and Born, who has the symbolic title of a professor that Walker might desire to achieve one day. Contrary to Walker, Born is suffused with death drive; something that destroys the ordinary way of life the subject takes because of his/her positionality in the symbolic universe. Actually what Born does to him is to derail Walker from his positional self in symbolic order which had in the first hand formed his life as a language-centered subject, so as Zizek says in The Parallax view:

The paradox of the Freudian "death drive" is therefore that it is Freud's name for its very opposite, for the way immortality appears within psychoanalysis, for an uncanny excess of life, for an "undead" urge which persists beyond the (biological) cycle of life and death, of generation and corruption. The ultimate lesson of psychoanalysis is that human life is never "just life": humans are not simply alive, they are possessed by the strange drive to enjoy life in excess, passionately attached to a surplus which sticks out and derails the ordinary run of things (62).

Living in excess but being lost amid the forest of signifiers, striving to seem successful under the gaze of the big Other, and the war that Born talks about in general are emblematic of human's wild inclination toward annihilation since the war always threatens the stability of the symbolic order. For Born it is bitter and intolerable to hear the destruction of the non-existent locus where all his hope lies, on the other hand, he is disillusioned with the dominating symbolic order of his own country as well as the one he seeks resort to in France, which will be clear at the end of the novel. In fact, Born is tactful enough to discern the trace of the Real in the war which may eradicate all the apparatuses of the symbolic order in the blink of an eye. According to Lacan, due to deformations the subject undergo in its identifications with fragmentary and alienating images in the imaginary order, the entrance into symbolic order becomes of necessity to form an anticipated, integrated self. Upon entering the symbolic order human is influenced by a transcendentalism in this order. As Lewis states by drawing upon Lacan's ideas:

If every human being as such suffered from the imaginary deficit and yet the human species survived, the symbolic supplement must have arisen concomitantly with their emergence, such that the human species was itself always symbolic and the development of the human being is the development of the symbolic order of culture. And indeed, once again, in this regard, some features of the imaginary form of the human being engender the symbolic order. So, once again, the mediation between symbolic and real is imaginary (Lewis 67).

Thus, for Walker, still lying in the mediation of the imaginary by his nurturing idealistic notions of being a great author, whatever threatens the symbolic order, like war, is absurd, all transcendentalism that Walker aims to achieve is in the realm of the symbolic as he pushes himself to the limits so as to form a reputable self in that order. However, Born, even though he is a professor and holds a great symbolic order, goes on creating gruesome scenes that are not interesting to Adam:

I'm talking about the pleasure of seeing men break each other's skulls open, of watching castles crumble and burn, of seeing the dead with lances protruding from their sides. It's gory stuff, believe me, and de Born doesn't flinch. The mere thought of a battlefield fills him with happiness. I take it you have no interest in becoming a soldier.

None. I'd rather go to jail than fight in Vietnam .

And assuming you avoid both prison and the army, what plans?

No plans. Just to push on with what I'm doing and hope it works out (Auster 11).

As it is clear from the conversation above, this is the beginning of the way Born precipitates the downfall of Walker from his everyday reality which is bound by the symbolic universe; this is the beginning of his disillusionment with the values he respects before he meets Born. This derailment and downfall will be expatiated upon after we account for the way Born turns into what Zizek call 'fantasmatic spectre'.

\section{The Masks of Fantasmatic Specter in Parallax Views}

In his essay, Between Symbolic Fiction and Fantasmatic Specter: Toward a Lacanian Theory of Ideology, Zizek analyzes Orson Welles's adaption of Kafka's The Trial which "accomplished an exemplary anti-obscurantist operation by way of reinterpreting the place and the function of the famous parable on the door of the Law." To Welles, the usual and predominant approaches to Kafka have always been obscurantist, and he finds Joseph K guilty due to his "naïve protestation of innocence, his arrogant reliance on naïve-rational argumentation", when "Court appears to K. as a mysterious and obscene agency", Welles further says:

Kafka is a deeply ambiguous writer who staged the fantasmatic support of the totalitarian bureaucratic machinery, yet was himself unable to resist its fatal attraction. Therein resides the uneasiness felt by many an 'enlightened' reader of Kafka: in the end, did he not participate in the infernal machinery he 
was describing, thereby strengthening its hold instead of breaking its spell? (qtd. in Zizek, Interrogating The Real 218).

Walker is also young and fascinated by the symbolic order and watches himself from the gaze of the big Other .From the moment he meets Born, who plans to invest some money by starting a publishing house to write articles and reviews, Born turns out to be the gaze of the big other that Walker should satisfy:

My father died ten months ago, and it appears I've inherited a considerable amount of money. Not enough to buy a château or an airline company, but enough to make a small difference in the world. I could engage you to write my biography, of course, but I think it's a little too soon for that. I'm still only thirty-six, and I find it unseemly to talk about a man's life before he gets to fifty. What, then? I've considered starting a publishing house, but I'm not sure I have the stomach for all the long-range planning that would entail. A magazine, on the other hand, strikes me as much more fun (Auster 15).

Born, as mentioned, turns into the controlling gaze, just like the way Kafka, according to Welles, stages fantasmatic support of the totalitarian bureaucratic machinery, and strengthens the hold of the spell this machinery has. Walker goes on perceiving Other of the Other in Born, and as the novel moves on, he thinks that Born was a mysterious person that pulled the strings and ran the show influentially. According to Zizek, Lacanian Other of the Other points to the power behind the visible, public power. There is another obscene, invisible, 'crazy power structure', This hidden Law plays the part of the 'Other of the Other' in the Lacanian sense, the part of the meta-guarantee of the consistency of the big Other (the symbolic order that regulates social life) (Zizek, Interrogating The Real 218-19). Little by little, because of his mysterious personality, Born turns into an enticing person or a master signifier, the more he becomes more accessible, the more he becomes horrible.

What Born provides for Walker's life is a fantasy which is transgressive of the symbolic order. As the subject's fantasies are its replies to the questioning gaze of the Other, which is represented here in Born's existence as a fantasmatic spectre, it's necessary for us to shed light on Walker's fantasies in regard to Born's presence. Here it is important to note that it is qua function that fantasy is inherently transgressive, not necessarily qua content. In other words, "its content simply comprises the usual elements of a fascinating Thing qua object of desire (whether beatic or horrific) and the narrative context, including the obstacle preventing access to the desired Thing (Glyson 202)." For Walker, Born is also transgressive and little by little becomes the object of desire, of course a horrific one .Born always prevents access to the desired Thing which is himself. The farther the object of desire is, the more alluring it gets; the more one nears it, the more it changes into something frightening. Qua performance, the fantasy hides and conjures the final horror of the real impasse portraying the integral deficiency of the symbolic order, thereby involving the subject in a discord of pains and the subsequent rewards (ibid). For Walker, such a business offer Born gives to him, such a great help, is the intrusion of great discord in his symbolic universe. As an American man, he knows well his dreams comes true with hardworking, but such a discord bears the fruit of doubt for Walker. Even when Walker meets Born two days after their first encounter, he forms a dark fantasmatic space against Born:

Curiously, my first impulse was to turn around and walk out without saying hello to him. There is much to be explored in this hesitation, I believe, for it seems to suggest that I already understood that I would do well to keep my distance from Born, that allowing myself to get involved with him could possibly lead to trouble. How did I know this? I had spent little more than an hour in his company, but even in that short time I had sensed there was something off about him, something vaguely repellent (Auster 13).

What is so appalling about Born for Walker is simply his ideas regarding death as we discussed earlier by drawing upon Zizek's analysis of Freudian death drive. Walker further says:

Would I have formed a different impression of him if I hadn't despised his politics? Impossible to say. My father and I disagreed on nearly every political issue of the moment, but that didn't prevent me from thinking he was fundamentally a good person - or at least not a bad person. But Born wasn't good. He was witty and eccentric and unpredictable, but to contend that war is the purest expression of the human soul automatically excludes you from the realm of goodness (Auster 18).

Thus, according to what Walker says, it is clear that he is in search of superegoic good and bad, and Born, who holds such ideas that threaten the symbolic order, seems to be evil; however, when their conversation progresses, Born turns into someone who can provide what Walker's symbolic universe offers in many years of hardworking and diligence, thus, as discussed earlier, Walker is lead to discord. In less than an hour, with his offer, Born turns into Walker's object cause of desire. This discord pushes us into drawing upon the concept of Kantian antinomy and then Zizekean parallax view. According to Zizek, antinomy as something irreducible

... conceive[s] the point of radical critique not as a determinate position as opposed to another position, but as the irreducible gap between the positions - the purely structural interstice between them. Kant's stance is thus to see things 'neither from his own viewpoint, nor from the viewpoint of others, but to face the reality that is exposed through difference (parallax) (Zizek The Most Sublime Hysterics 121-22).

So, the changing position of Walker's defines who Born is. This antinomy or the internal conflict cannot be pinned down to one simple reason and the reality should be defined by the parallax difference. In his magnum opus, Parallax View, Zizek defines Parallax as: 
The standard definition of parallax is: the apparent displacement of an object (the shift of its position against a background), caused by a change in observational position that provides a new line of sight. The philosophical twist to be added, of course, is that the observed difference is not simply "subjective," due to the fact that the same object which exists "out there" is seen from two different stances, or points of view (Zizek, The Parallax View 17).

Given the definition above, in general, this novel shows how Born is seen from different parallax views, and in the four different chapters of the novel, we find out more about this definition of Parallax. Even though Walker knows well about the fundamental beliefs that Born holds, which are of course disgusting to him, he keeps on satisfying the dominating gaze of the Other. He does not want to simply believe that Margot was the only and main reason for which Born approached him and gave him the business offer, he wants to believe in and realize the dreams that come from working hard, thus he pushes himself to the limits to satisfy the gaze:

It took me longer to finish the prospectus than I'd imagined it would-four or five days, I think, but that was only because I did such a thorough job. I wanted to impress Born with my diligence, and therefore I not only worked out a plan for the contents of each issue (poetry, fiction, essays, interviews, translations, as well as a section at the back for reviews of books, films, music, and art) but provided an exhaustive financial report as well: printing costs, paper costs, binding costs, matters of distribution, print runs, contributors' fees, newsstand price, subscription rates, and the pros and cons of whether to include ads (Auster 19).

To put it more clearly, as Hegel would have put it, subject and object are inherently "mediated," so that an "epistemological" shift in the subject's point of view always reflects an "ontological" shift in the object itself (Zizek, The Parallax View 17). Similarly, since Born and Walker are inherently mediated, Walker's epistemological understanding of Born undergoes huge changes as Born's ontological status of Born is transformed, too. To put it in Lacanese terms, the subject's gaze is always-already inscribed into the perceived object itself, in the guise of its "blind spot," that which is "in the object more than the object itself," the point from which the object itself returns the gaze (ibid).Here, the object, Born, returns Walker's gaze while Walker himself, as the subject, has to reply to the dominating gaze of the big Other, Born. Surprisingly, the distinguishing line between objectivity and subjectivity is blurred. To explain how such blurring ends in different trends of subjectivity, we need to apply Zizek's ideas about parallax views. Considering Kantian antinomy and the parallax gap, Zizek considers object petit $a$ as the best example of the parallax object. As Zizek says, object petit a brings about a change when subject shifts its position and it is "the very cause of Parallax gap, that unfathomable $\mathrm{X}$ which forever eludes the symbolic grasp, thus causes the multiplicity of symbolic perspectives (ibid)" which lead to disparate courses of subjectivity. To clarify it more, Born acts as both reified big Other and object petit for Walker. Walker in his different encounters with Born experiences disparate Zizekean parallax views. Each of such views pushes Walker into standing in the middle of the various tends of subjectivities; in fact, Walker's multiplicity of 'symbolic perspectives' in regard to Born's existence as a fantasmatic spectre, object petit and big Other results in his interwoven subjectivity.

\section{Encounters with the Real}

What is so interesting about Born is that he performs a role that is just like the definition of Lacanian Real which cannot be substantiated at all, it is nothing besides the 'thread that ties together' the symbolic and the imaginary. The real-ofthe-symbolic is the letter (epitomized in both meanings, in the constituents of a word and in a written message), while the real of- the-imaginary is the objet petit $a$, the object-cause of desire which is encountered in the fantasy, "the symbolic's mythical yet imaginary depiction of its own origins, of that which was lost due to the emergence of the symbolic and which our desire apparently strives to recapture (Lewis 151)." Born is the Real of the symbolic in that talks about the war and its unfathomable trace of the Real which is going to crush the whole human world, the symbolic order. This fact is more underpinned when we notice that death has a cryptic presence in his name Born (given birth). $\mathrm{He}$ is also the Real of the imaginary as he appears to be an object petit a for Walker. We should not forget that without symbolic order, human is but animal, thus, according to Lacan, animality carries the traces of the Real within itself. The moment Born talks erotically about his partner Margot and asks Walker if he would sleep with her, he shows the animalic side of the Real. The Following paragraph illustrates the way Born shows his animalic side to Walker:

And what about Margot herself? Are you attracted to her as well?

She's sitting right across the table from me. It seems wrong to talk about her as if she weren't here. I'm sure she doesn't mind. Do you, Margot?

No, Margot said. Not in the least.

You see, Mr. Walker? Not in the least.

All right, then, I answered. In my opinion, Margot is a highly attractive woman.

You're avoiding the question, Born said. I didn't ask if you found her attractive, I want to know if you are attracted to her (Auster 22).

Another time when Born elucidate the animality of human being is when he is drunk at the party:

Bombastic pronouncements, wild generalizations, bitter declarations about the corruption of all governments - past, present, and future; left, right, and center — and how our so-called civilization was no more than a thin screen masking a never-ending assault of barbarism and cruelty. Human beings 
were animals, he said, and soft-minded aesthetes like myself were no better than children, diverting ourselves with hairsplitting philosophies of art and literature to avoid confronting the essential truth of the world (Auster 25).

To elucidate the point, it would be better to draw upon Jungian concept of shadow which is so close to the Lacanian Real of the imaginary. Aaccording to Jung, shadow is an unconscious side of the individual's personality which is not recognized by the conscious ego as a part of it. Owning to the fact that an individual keeps shunning or staying unaware of the least desirable sides of his/her personality, the shadow is perceived to be negative to a great extent, or to be the totality of the unconscious which means everything of which a person is not completely conscious. Yet, there are positive sides which may also remain covert in individual's shadow, particularly in people with low self-esteem (Eisendrath and Dawson 319).

Born, it can be said, is Walker's shadow because little by little the things Walker experiences with Born on his side lead to the rise of his dark side. His idealized images which are so important to him get lost when Born as the main agent of his symbolic order does heinous things that have no place in his symbolic universe. One of the main reasons that might be the cause of Born's attraction to Walker is that Born as the shadow or the animalic side of this story is fascinated by the unrestrained aspect of a poet's charcater that he thinks Walker may have, or the reverse may be quite true, because as a man who is fascinated by the chaotic issues such as war and revolution, he may see Walker as an individual who is too wrapped and sunk in the undisturbed peace while the world is in flames, so when Born is with Walker, he might be unconsciously attracted to Walker in order to deflower his virgin mind with his active animalic and shadowy side. Margot and Born both view him as the oppressed and starved. The following conversation sheds light on this supposition:

She thinks you need help. Margot might not possess the quickest brain in the Western world, but she meets a boy who says he's a poet, and the first word that comes to her is starvation.

That's absurd. She has no idea what she's talking about.

Forgive me for contradicting you, but when I asked you at the party what your plans were, you said you didn't have any. Other than your nebulous ambition to write poetry, of course (Auster 14).

In fact, Born as the mysterious Other of the Other has its fantasmatic existence for Walker in many ways, one of which is his surreptitious existence as the trace of the Real, both as the Real of the symbolic (in his speech on war and his mysteries name) and the Real of Imaginary (his being as an object petit a for Walker). Moreover, by his introducing Margot to Walker, Born hurls him to the wild animalic realities that exceed the ordinary moral codes internalized in him. Another scene which generates dark fantasmatic space is Born's act of stabbing the kid, which is found heinous by Walker. Besides his first stab that knocked the threatening kid down, Walker found out that the kid was stabbed other several times after his death, although it never became clear if it was done by Born or not. Born's encounters with the Real, represented in Born, involve him in the two different trends of subjectivities, both in the imaginary and the symbolic; that's why we call such encounters interwoven subjectivity.

\section{Between Two Deaths: an Aporia}

Zizek says we can die not just once, but twice. Most obviously, we will suffer a biological death in which our bodies will fail and eventually disintegrate. This is death in the Real, involving the obliteration of our material selves. But we can also suffer a Symbolic death. This does not involve the annihilation of our actual bodies; rather it entails the destruction of our "symbolic universe and the extermination of our subject positions (Myers 74-5)."

When Walker is dying of leukemia, he is between two deaths, he has not achieved the image of an ethical man, since Born has slipped out of his hand and has remained the other of the other, he hasn't been able to be an accomplished literary man and writes a poorly-styled novel in order to take his symbolic position back in life at least. Walker is hell bent on identifying himself with the signifiers that provide him with an alienating symbolic identity, and to better say, an impossible identity. But in fact this identification entangles him in an Aporia of logical or rhetorical perplexities, impassable difficulties, logical paradoxes, and puzzlements that even causes his friend Jim to wonder more:

But what kind of help could I give him? He was having trouble with his book, and for some inexplicable reason he had deluded himself into thinking I had the power to say the magic words that would get him started again. Did he expect me to hand him a prescription for a pill that cured struggling authors of their writer's block? (Auster 42).

The Aporia delimits a slippery point where identity as a textual entity, in Derrida's terminology, disassembles itself, deconstructs itself, or destabilizes its own rhetorical foundations (Derrida 14-20). Therefore, Walker just indulges in a linguistic game of identity and difference, as he find himself self-identical with the difference lying at the root of his identity. Derrida argues about "the structural indeterminacy of textual aporia" and focuses on how undecidability is crucial for any understanding of political action and for understanding the very possibility of justice in our world (Bates 2). Born's life is exactly tantamount with the mechanism of Derrida's Aporia because at the end of the novel when Cecil goes to him, he explains how he was stuck between two opposite parties, worked as a double agent and the result of a lifetime political activity was disillusionment.

Back to the discussion about "between two deaths", Zizek furthers his argument by saying that the gap between two deaths can be filled "either by manifestations of the monstrous or beautiful". For instance, Hamlet's father in Shakespeare's Hamlet, is between two deaths, he is dead in the Real, yet he haunts them as a monstrous and terrifying 
apparition since before settling his symbolic debts, he was murdered. When his son kills his murderer and his symbolic debt is repaid, he is totally dead (Zizek, The Most Sublime Hysterics 201) In the beginning of chapter two, in the dying Walker's letter, Born is depicted as a monstrous image .He is supposedly dead in the Real, however, Walker has not been able to annihilate him symbolically. By writing his novel and revealing Born's deeds, Walker aims to exterminate Born's position as the invisible Other of the Other, thereby bringing a symbolic death to him. But, what propels Walker into killing Born symbolically? The answer is the call of enjoyment invoked by superego. Walker is the offshoot of what Zizek calls "societies of commanded enjoyment (Zizek, How to Read Lacan 58)." Actually enjoyment turns into a duty for him, duty to annihilate Born: "duty is metamorphosed into a duty to enjoy, which is exactly the commandment of the superego (ibid)." Lacan was definitely one of the first to elaborate upon the significance of this "paradoxical hybrid' when he connected the command "enjoy!" with the superego: "The superego is the imperative of jouissanceEnjoy!" (Stavrakakis, Beyond the Spirits 45). Even though Walker seems to take a moral action approved by the superego for justice, he unconsciously enjoys killing Born by exacting revenge on him and fulfills his forbidden desire. These two sides of Walker's writing is the paradoxical nature of his interwoven subjectivity.

The strong presence of superego in Walker's psyche leads him to be so judgmental and sceptic. Even when Born invites him to his partner's house and talks highly of him, he senses some conspiracy going on under. An internal violence has made Walker ablaze and he is blind to any good from Born's side. Such destructive inclinations prove Zizek's argument as he affirms that the outbreak of Real violence is conditioned by a symbolic deadlock. "Real violence is a kind of acting out that emerges when the symbolic fiction that guarantees the life of a community is in danger (Zizek, Interrogating the Real 223)." For Walker, Born is the Real of the imaginary and the symbolic, Any goodness from his side is considered by Walker as threatening and as the Real violence, since he needs a pure evil to buttress his symbolic fiction by which he makes a hero out of himself. When such symbolic fiction is in imminent danger, the Real violence is felt more strongly by Walker.

Zizek says that the best way to account for this violence is to look at the problem from the other end: "what is the purpose lurking behind the outbursts of violence? What do we want to achieve, what do we try miserably to destroy, when we kill Jews or beat up foreigners in our cities (ibid)? Zizek's answer is that the main purpose behind the rapes of Bosnian war, for instance, is to debase the fiction or the symbolic narrative that guarantees the coherence of the Muslim community. What Zizek further asks is that "what do they harbor in them that is annoying to us and disturbs our psychic balance? Foreigners may be similar to us in appearance and behavior; however, there is some unfathomable je ne sais quoi, something 'in them more than themselves' that makes them 'not quite human' (ibid)."

For Walker, Born is such a paradoxical uncanny object that is the symbol of what, in the discerned positive, empirical object, necessarily eludes Walker's gaze, thereby working himself out as the driving force of Walker's desiring him as an objet petit a, the object-cause of desire; another name for this driving force is plus-de jouir, the 'surplus enjoyment' that designates the "excess over the satisfaction brought about by the positive, empirical properties of the object (ibid)." Violence in general sense and in Walker's case is exactly an attempt to strike a blow at this intolerable surplusenjoyment harbored in Born, who leads Walker to desire him as an object petit a . Therefore, because antipathy is not restricted to the 'actual properties' that Born has, but 'targets its real kernel, objet petit $a$, what in the object is more than itself', the object of hatred is stricto sensu indestructible: the more we destroy the object in reality, the more powerful its sublime kernel rises in front of us. This paradox has already emerged apropos of the Jews in Nazi Germany: "the more they were ruthlessly exterminated, the more horrifying were the dimensions acquired by the remainder (ibid)". The same applies to Walker when he goes on destroying Born, but he comes back to him more strongly and will haunt his life more powerfully. In a nutshell, Walker, on the one hand, feels Real violence from Born's side as he thinks his symbolic fiction is in danger. On the other hand, he shows his cruel hatred to Born as he senses his Real kernel, object petit a, something in Born more than him. These two courses of subjectivities both attract him to and distance him from Born; such suspension manifests Walker's interwoven subjectivity in its radical form of the Aporia of logical perplexity.

\section{Traversing Fantasy}

Walker's life is the emblematic of an unfulfilled enjoyment when he writes a letter to Jim at the end of his life since he has never been able to traverse the fantasy. By referring to The Matrix and Inception we will elucidate the point. Unlike Neo (Keanu Reeves) in The Matrix, who "breaks free and changes the coordinates of his relationship to ideology and involves maintaining a safe distance between himself and the virtual world of symbolic reality- the matrix itself as the technological medium of appearances representing reality-', Walker is unable to break free. On the other hand, Inception' case is much severer. So as to flee from the universe of symbolic fictions, the protagonist, Cobb (Leonardo DiCaprio), is needed not only to preserve a distance between himself and the symbolic "reality." He has to go even deeper and deeper: "he must identify with and risk the inner most kernel of his very being (Flisfeder 2)." He must traverse the very fantasy that structures his approach to reality itself.

For the first time in the spring Walker faces the traumatic Real when Born, as the gaze of the Other, stabs the kid; however in France he is unable to delve deeper like Cobb, and before he finds that Born, as the Other of the other, is but a disillusioned double agent with no substance, he is captured and deported back to the States. Paul Auster directs his characters to traverse their fantasies to find out the unfulfilled enjoyment (jouissance). Born is the one who has traversed the fantasy and at the end of the novel, he is no longer disturbed like Walker, he is not paralyzed by the hidden Other of the Other, he has found that nothing exists behind the curtain, he ventures baring his soul to Cecil, telling him how he was the reason that his father had been hurled into coma: 
It's summer. Mr. Y and his family are vacationing in the mountains somewhere in the south of France. Mr. X goes down there, sneaks onto the property in the middle of the night, and disconnects the brakes of Mr. Y's car. The next morning, on his way into town to buy bread at the local bakery, Mr. Y loses control of the car and crashes down the side of a mountain. Mission accomplished (Auster 125).

In his In Defence of Lost Causes, Zizek sheds light on two definitions of anxiety which is crucial in showing how Born traverses the fantasy, but Walker cannot. Walter Benjamin discriminates between 'constituted anxiety' and 'constituent anxiety' which are important, concerning the shift from desire to drive. The first points to the 'standard notion of the terrifying and fascinating abyss of anxiety which haunts us" and "its infernal circle ... threatens to draw us in (327)." This first anxiety belongs to Walker, where he ventures acting like an enthusiastic hero. The second anxiety stands for the 'pure' confrontation with the objet petit $a$ as constituted in its very loss and belongs to disillusioned Born. The difference splitting constituted anxiety from constituent one results from the status of the object of desire regarding fantasy. In case of constituted anxiety, the object dwells within the confines of a fantasy. For Walker, Born ,as object of desire, remains monstrous till the end of Walker's life, and stays within the confines of his fantasy, therefore, it is Walker who feels constituted anxiety. Nonetheless, we get the constituent anxiety only when the subject "traverses the fantasy" and confronts the void, the gap, filled up by the fantasmatic object (327-8). In case of Born, the fantasmatic object lies in the heart of the West that has lost its charisma; Born, when relating his story to Cecil, recounts it in third person:

-Any number of reasons. After years of work in the field, he becomes disillusioned with the West and converts to the Communist cause. Or else he's a cynic who doesn't believe in anything, and the Russians are paying him good money, more money than the French are paying him, which means that he's earning more than twice as much as he would if he worked for just one side (Auster 124).

In fact, Born traverses the fantasies caused by the lost charisma of western life, thereby undergoing constituent anxiety. The two aforementioned anxiety can be illuminated in terms of the paradoxical nature of object petit a.

Zizek says that Alain Miller misses the true paradox of object a when he limits it to the horizon of desire, but Lacan emphasizes, the object $a$ is also the object of the drive although, in both cases, the link between object and loss is crucial. In the case of the objet $a$ as the object-cause of desire, we have an object which is originally lost, which coincides with its own loss, which emerges as lost, while, in the case of the objet a as the object of the drive, the "object is directly the loss itself- in the shift from desire to drive, we pass from the lost object to loss itself as an object (italicized by Zizk)(Zizek, In Defence of Lost Causes 328)."

What we find out at the end of the novel is how two different characters have led their life through storms to find the truth. For Walker object $a$, as the object cause of desire, is lost and what he desperately wants by writing a novel is the gaze of the Other paying attention to him. He seems to be filling his novel with the outburst of his erotic desires which are denied by his sister, and even on his deathbed he wants the lost object (Born) to be back. Therefore, his object dwells within the confines of his fantasies and he feels constituted anxiety. However, in the case of object a as the object of drive, the object is loss itself for Born. Born knows that his values lie nowhere, neither in the West, nor in Communist cause. His object of drive in which Born directly enjoys loss itself simply does not pop up in his ontological horizon. Consequently, he never indulges in fantasies caused by the loss of object-cause of desire; he traverses such fantasies and feels the constituent anxiety. What is very insightful here is the fact that any individual may encounter such paradoxical nature of object petit a. As the subject encounters the object a as the object-cause of desire he faces the lost object. But, facing the object of drive, the subject undergoes the loss itself as an object. The fluctuation between lost object and the loss itself, as an object, plums the depth of the anxieties embedded in such interwoven subjectivity.

\section{Conclusion}

As literary critics mention, Auster's literary world is replete with the contingent events. This motif has been pinpointed in the urban environment of New York City. The conception of the author is another issue that Auster submits into scrutiny. He tends to invite his readers to determine the fate of his protagonists and deconstruct the binary opposition between reader and author. Although these motives are also recurrent in Auster's Invisible, we, in this article, have examined the novel in terms of the characters' psychological attempt to form their different identifications within Lacanian theoretical framework. Born acts as both reified big Other and object petit for Walker, while Walker in his different encounters with Born become entangled with disparate Zizekian parallax views. Each of such views leads Walker to stand in the middle of the various courses of subjectivities and experience an intricate, interwoven subjectivity. Furthermore, we have shown Walker's encounters with the Real, represented in Born, push him to adopt two different subjective stances in the imaginary and the symbolic order and, consequently, his constant Symbolic identifications with signifying traits of Born's bring him nothing but an aporia of logical perplexities. More importantly, we have emphasized that the fluctuation between lost object and the loss itself, as an object, plums the depth of the anxieties embedded in such interwoven subjectivity.

\section{Reference}

Auster, Paul, Invisible, New York : Distri, 2013. Print.

Bates, David. Crisis Between the Wars: Derrida and the Origins of Undecidability. University of California, 2005. Print. 
Derrida, Jacques. Of Grammatology, trans. Gayatri Chakravorty Spivak, Baltimore: Johns Hopkins University Press, 1976

Fleck, Linda L..“ From Metonymy to Metaphor: Paul Auster's Leviathan” . Paul Auster. Philadelphia: Chelsea House Publishers, 2004. Print

Flisfeder, Matthew. The Symbolic, The Sublime, And Slavoj Žižek's Theory Of Film. New York: Palgrave Macmillan, 2012. Print.

Glyson, Jason. The grip of ideology: a Lacanian approach to the theory of ideology. Journal of Political Ideologies, 2001. Print.

Lewis, Michael. Derrida And Lacan. Edinburgh: Edinburgh University Press, 2008. Print.

Martin, Brendan. Paul Auster's Postmodernity. New York: Routledge, 2008. Print.

Momeni, Javad and Rasoul Mohsenzadeh. "The (In)Visible Eye Of Authority: Notes On Surveillance In Paul Auster'S Ghosts". ILSHS 61 (2015): 82-86. Web.

Myers, Tony. Slavoj Zizek. Routledge Press, 2003. Print.

Russell, Alison ." Deconstructing The New York Trilogy: Paul Auster's Anti-Detective Fiction” . Paul Auster. Philadelphia: Chelsea House Publishers, 2004. Print

Stavrakakis, Lacan and the Political, Yanis, London: Routledge, 1999.

Stavrakakis, Yannis. Beyond The Spitits OF Capitalism? Prohibition, Enjoyment, And Social Change, Aristotle University of Thessaloniki, 2011. Print

Weisenburger, Steven . "Inside Moon Palace”. Paul Auster. Philadelphia: Chelsea House Publishers, 2004. Print

Woods, Tim ."Looking for Signs in the Air: Urban Space and the Postmodern in In the Country of Last Things" . Paul Auster. Philadelphia: Chelsea House Publishers, 2004. Print.

Young-Eisendrath, Polly and Terence Dawson. The Cambridge Companion To Jung. Cambridge [Cambridgeshire]: Cambridge University Press, 1997. Print.

Zilcosky, John ." The Revenge of the Author: Paul Auster's Challenge to Theory”. Paul Auster. Philadelphia: Chelsea House Publishers, 2004. Print.

Žižek, Slavoj and Glyn Daly. Conversations With Zizek. Cambridge, UK: Polity, 2004. Print.

Žižek, Slavoj, Rex Butler, and Scott Stephens. Interrogating The Real. London: Continuum, 2006. Print.

Žižek, Slavoj. Between Symbolic Fiction and Fantasmatic Specter: Toward a Lacanian Theory of Ideology,New Left Review, 2004. Print.

Žižek, Slavoj. In Defense Of Lost Causes. London: Verso, 2008. Print.

Žižek, Slavoj. The Most Sublime Hysterics: Hegel with Lacan.Polity Press, 2014. Print.

Žižek, Slavoj. The Parallax View. Cambridge, Mass.: MIT Press, 2006. Print.

Zizek, Slavoj. How to Read Lacan. New York: W.W. Norton \& Co, 2007. Print. 